\title{
The New Real Property Registration Structure in China: Progress with Unanswered Questions
}

\author{
$\mathrm{Lu} \mathrm{Xu}{ }^{*}$
}

\section{Abstract}

Since March 2015, China has been implementing a nationwide unified real property registration structure. This article explains the objectives and measures of this ambitious project against the background of the current system which is fraught with complexity, difficulties and local variations. The move represents significant progress in the regulation and administration of real property in line with the vision of streamlined registration explicitly provided for in statutes such as Property Law of PRC (2007). Nevertheless, within this undoubtedly positive reform, the currently unclear relationship between property law and property registration is left unattended to. With reference to comparative materials from England, Scotland and Australia, this paper identifies some of the unanswered questions that would have serious implications on the integrity and reliability of real property register as a whole, especially in the context of fraud and forgery.

\section{Introduction}

In November 2014, the State Council of China issued the Interim Regulations on Real Property Registration. ${ }^{1}$ Signed off by Premier Li Keqiang, the Interim Regulation commenced on $1^{\text {st }}$ March 2015 with the plan to establish a nationwide, unified real property registration system in three years. Apparently endorsed with the responsibility to direct and supervise real property registration across the country, ${ }^{2}$ the Ministry of Land and Resources duly issued a draft Implementation Rules for public comment on $26^{\text {th }}$ March 2015. ${ }^{3}$ The consultation closed after 30 days with the final Implementation Rules expected to be in force before the end of $2015 .^{4}$

\footnotetext{
${ }^{*}$ Senior Lecturer in Property Law, Lancaster University. I am grateful to Professor Keyuan Zou and his colleagues at University of Central Lancashire Law School for organising the Rule of Law and Chinese Legal Reform Conference in May 2015, where this paper was first presented. All mistakes and omissions remain my own.

${ }^{1}$ Order No. 656 of the State Council, 《不动产登记暂行条例》, herein after referred to as “Interim Regulations". Chinese full text available on the website of PRC Central Government: www.gov.cn/zhengce/content/2014-12/22/content 9325.htm (accessed 1 September 2015).

${ }^{2}$ Interim Regulations, Article 6 . Article 6 does not specifically identify the Ministry of Land and Resources. Instead it prescribes for "the department of the State Council that primarily manages land and resources", which would be the MLR as things stand.

3 《不动产登记暂行条例实施细则 (草案征求意见稿)》, herein after referred to as “draft Implementation Rules". Chinese full text available on the website of the Legislative Affairs Office of the State Council: http://www.chinalaw.gov.cn/article/cazigg/201503/20150300398788.shtml (accessed 1 September 2015).

${ }^{4}$ Draft Implementation Rules, Article 137.
} 
This ongoing process of regulation and implementation could be another major step in the decade-long construction of a unified real property registration structure in China. Such ambition was most unambiguously stated in Property Law of the People's Republic of China, enacted in 2007. ${ }^{5}$ Article 10 of the Property Law states that the State implements a unified registration system for immovables. However, the scope, organisation and methods of such registration system are to be governed by unspecified "law and administrative regulations". The Interim Regulations of 2014 is the most substantive piece to-date that fits this description. This paper will analyse the existing structure for registration and the progress that the Interim Regulations can bring in realising the ambition of unified real property registration.

Meanwhile, for a property lawyer, there seems to be something missing from the Interim Regulations and the very detailed draft Implementation Rules. Though ostensibly authorised by Property Law of PRC amongst other law, ${ }^{6}$ the Interim Regulations and the draft Implementation Rules make very little effort to regulate the relationship between property law and the real property registration system they are envisaging and implementing. A number of key questions that would define the fundamental values and policies of a real property registration structure are not answered or, more precisely, not being asked in an implementation process that has already started. Drawing on comparative law materials, this paper seeks to identify the key uncertainty in a real property registration framework. With little attention being paid to some of these core principles and effects of registration, it seems rather unnerving for any jurisdiction to implement a new property registration structure, let alone what would likely become the largest property registration structure in the world.

\section{Status Quo of Real Property Registration in China}

In order to appreciate the impact that the Interim Regulations could potentially have in the area, it is helpful to have some understanding about the current system for registering various rights in real property. It would be fair to suggest that the existing system in China is highly divided, cumbersomely repetitive, as well as greatly varied across different parts of China.

(i) National Law and Regulations

It should be noted that under Chinese law most land is owned by the State. ${ }^{7}$ Only some rural land, including some forest, grassland, marshland and so on, can be collectively owned by the rural population of the area as authorised by law or regulations. ${ }^{8}$ The most that any individual or organisation can hold in terms of right to land is the right to use land within a specified period such as fifty or seventy years, renewable according to the nature of the usage. ${ }^{9}$ Against such background and in relation to right to land usage, Law of PRC on Land Administration

\footnotetext{
5 《中华人民共和国物权法》. Future references to the full title of primary legislation will adopt "PRC" as an abbreviation for "the People's Republic of China".

${ }^{6}$ Interim Regulations, Article 1 states that the Regulations were made according to "Property Law Act of the People's Republic of China and other law".

${ }^{7}$ Constitution of PRC, Article 10.

${ }^{8}$ Property Law of PRC, Articles 46-48.

${ }^{9}$ Property Law of PRC, Article 149.
} 
provides the clearest example of the division in registration arrangements. ${ }^{10}$ Land collectively owned by the rural population, whether for agriculture or non-agriculture use, is registered by county-level government. Land used by other organisations or individuals should be registered by government at county-level or above. ${ }^{11}$ The registration authority for land used by central government organs is specified by the State Council. ${ }^{12}$ In practice, the Ministry of Land and Resources entrusted such registration to the Land, Resources and Housing Administration Bureau of Beijing Municipality. ${ }^{13}$ Thus the top three administrative tiers of government ${ }^{14}$ have all been given the statutory authority to administer land registration, creating considerable variation in every aspect of registration. Moreover, while the right to use land is registered by the local government as the main entity, some subsidiary rights in land such as mortgages and easements are registered only by the department for land and resources administration of the same government. ${ }^{15}$

The greater division of registration structure comes not only in governmental levels and departments, but also between land and buildings. The Law of PRC on Urban Real Estate Administration formally separates the registration of land usage rights and building ownership into different registries run by different government department. ${ }^{16}$ Registration of land under the Law of Land Administration, as explained above, is primarily operated by the government department for land administration at the corresponding government level. On the other hand, building ownership over the same land is registered by the relevant government department for building and housing administration at county-level or above. ${ }^{17}$ Consequently, any ordinary owner of urban property must comply with two sets of separate registration rules and procedures from two different government departments for land and building in every transaction involving the real property. This artificial and unrealistic separation of physically inseparable subjects not only leads to greater inconvenience and higher costs for the parties in every transaction such as a sale or a mortgage, but also administrative and legal difficulties, such as where land and building were registered to different persons or entities.

The registration for rural land comes with even greater complexity. Land used for "house sites" (zhai ji di) must be registered with the county-level government department for land administration as right to use collectively-owned land. ${ }^{18}$ Building over such land, even though technically not covered by the Law of Urban Real Estate Administration, could nevertheless be registered under "Measures for Building Registration", issued by the former Ministry of Construction only a few weeks before its restructuring into the current Ministry of Housing

10 《中华人民共和国土地管理法》, first enacted in 1986, currently as amended in 2004.

${ }^{11}$ I.e. prefectural level or provincial/municipal level.

12 Law of PRC on Land Administration, Article 11.

${ }^{13}$ Order No.6 of the Ministry of Land and Resources (23 $3^{\text {rd }}$ October 2000), Article 3.

${ }^{14}$ Province or municipality level, prefecture level, and county-level.

15 “Measures for Land Registration” (《土地登记办法》), Order No.40 of the Ministry of Land and Resources (30 ${ }^{\text {th }}$ December 2007), Article 3. Chinese full text available on the website of the Ministry of Land and Resources: www.mlr.gov.cn/xwdt/zytz/200801/t2008010397843.htm (accessed 1 September 2015).

16 《中华人民共和国城市房地产管理法》, first enacted in 1994, currently as amended in 2007.

${ }^{17}$ Law of PRC on Urban Real Estate Administration, Article 61.

${ }^{18}$ Law of PRC on Land Administration, Articles 8 \& 11. 
and Urban-Rural Development in 2008. ${ }^{19}$ Land actually used for farming would normally give rise to right to contracted management (cheng bao jing ying quan), which requires registration under the Law of PRC on the Contracting of Rural Land by county-level government or above. ${ }^{20}$ The Ministry of Agriculture later issued "Measures for the Administration of Circulation of Rural Land Contracted Management Right" to further extend such registration responsibilities down to township-level government. ${ }^{21}$

Moreover, dependent on the nature or use of the land, there may be further registration requirements under other branches of law and government. For rights to trees, forest and woodlands not within designated "key forest zones", registration must be applied for through the forestry authority at county-level, but the actual registration is administered by the county-level government under the Forestry Law of PRC. ${ }^{22}$ Yet mortgage right of forest trees is directly registered by the forestry authority instead of the government under the Law of PRC on Guarantee..$^{23}$ Right to use grassland is registered by county-level government or above, while collective ownership of grassland is registered by county-level government. ${ }^{24}$ Right to aquaculture in waters and mudflats is applied for through the fisheries authority at countylevel or above, and then registered by the government of the same level. ${ }^{25}$

With such diversification, perhaps it is unsurprising that the right to use sea areas is also separately registered under the Law of PRC on the Administration of Sea Areas. ${ }^{26}$ Usage rights approved by the State Council are registered by the maritime administrative department of the State Council, which currently is the State Oceanic Administration as a subordinate agency to the Ministry of Land and Resources. Usage right approved by local government, on the other hand, are registered by the relevant local government, which could be county, prefecture or province level dependent on scale of the usage right. ${ }^{27}$

(ii) Local Variations

19 《房屋登记办法》, Order No.168 of the Ministry of Construction (15 ${ }^{\text {th }}$ February 2008), Articles 82 \& 83. Chinese full text available on the website of Ministry of Housing and Urban-Rural Development: www.mohurd.gov.cn/zcfg/jsbgz/200803/t20080321 159112.html (accessed 1 September 2015).

20 《中华人民共和国农村土地承包法》, first enacted in 2002, Article 38.

21 《农村土地承包经营权流转管理办法》, Order No.47 of the Ministry of Agriculture (19 ${ }^{\text {th }}$ January 2005), Article 27; Chinese full text available on the website of Ministry of Agriculture: www.jgs.moa.gov.cn/zcfg/tdcb/201010/t20101020 1684857.htm (accessed 1 September 2015). ${ }^{22}$ Forestry Law of PRC (《中华人民共和国森林法》), first enacted in 1984, currently as amended in 1998; Regulations on the Implementation of the Forestry Law (《森林法实施条例》), Order No.278 of the State Council (29 $9^{\text {th }}$ January 2000), Articles $4 \& 5$.

${ }^{23}$ Law of PRC on Guarantee (《中华人民共和国担保法》), first enacted in 1995, Article 42.

${ }^{24}$ Law of PRC on Grassland (《中华人民共和国草原法》), first enacted in 1985, currently as amended in 2013, Article 11.

${ }^{25}$ Fisheries Law of PRC (《中华人民共和国渔业法》), first enacted in 1986, currently as amended in 2013, Article 11. "Measures for Licensing and Registration of Aquaculture in Waters and Mudflats" (《水域滩涂养殖发证登记办法》), Order No.9 of the Ministry of Agriculture (24 $4^{\text {th }}$ May 2010), Articles 5-7. Chinese full text available on the website of the Central Government of PRC: www.gov.cn/flfg/2010-05/31/content 1617299.htm (accessed 1 September 2015).

26 《中华人民共和国海域使用管理法》, first enacted in 2001, Article 19.

${ }^{27}$ Order No.36 of the General Office of State Council (6 $6^{\text {th }}$ July 2002), Article 1. 
Thus there are at least nine statutes, enacted and amended over thirty years between 1984 and 2013, which explicitly provide for registration of some right in land, buildings and other immovables. They are of course supported by more than a dozen subsidiary "regulations", "orders" and "measures", creating a myriad of registration rules and practices. And these are only national legislation and regulations. Many municipalities, provinces and prefecture-cities have their own local variation or innovation. Some of these would modify or supplement the national regulations, while others effect much more profound change to the national framework. For example, after the commencement of "Measures for Building Registration" from the Ministry of Construction, mentioned above, Jiangsu Province issued "Guiding Opinion on Several Problems in the Implementation of 'Measures for Building Registration' in Jiangsu Province" through its Department of Construction in June 2009. ${ }^{28}$ The "Guiding Opinion" presented observation and explanation of a number of the provisions of the "Measures", but supplemented the "Measures" in areas where it remained silent or ambiguous. However, only a week later, on $1^{\text {st }}$ July 2009, neighbouring Shanghai Municipality saw the commencement of its own newly overhauled Regulations of Shanghai Municipality on Registration of Real Estate..$^{29}$ Unlike Jiangsu Province's relatively short "Guiding Opinion" which made twelve explicit references to the "Measures" from the Ministry of Construction in its twelve articles, the Regulations of Shanghai with 77 articles completely ignored the "Measures" which had supposedly been in force in the whole country for exactly twelve months. The resolution of any possible conflict between local regulations and regulations of a central government department is a heatedly debated topic, beyond the context of this paper. ${ }^{30}$ But it should suffice to observe that the current registration structure for real property in any municipality or province of China is considerably more complex than the web of nine statutes and twenty or so subsidiary instruments that often do not produce coherent or logical outcomes when put together.

Yet such local variations are not always undesirable for the population of a particular municipality or province. Where the national structure is inconvenient or inept, arguably local schemes could provide a better and more efficient system. Such local improvements are permitted and in many regards anticipated by the national legislature. ${ }^{31}$ After dividing registration into buildings and land by different government departments for all urban real property, Law of PRC on Urban Real Estate Administration, mentioned above, specifically allows local government to do it differently. Government at municipal or provincial level can determine that a single government department at county-level or above should administer

\footnotetext{
28 《江苏省实施<房屋登记办法>若干问题的指导意见》，Order No.196 of the Department of Construction of Jiangsu Province (24 ${ }^{\text {th }}$ June 2009). Chinese full text available on the website of the Department of Housing and Urban-Rural Development of Jiangsu Province:

jscin.gov.cn/web/zfxxgk/infodetail.aspx?id=551bc6a6-6d3d-470a-bc89-5112673e7fb1 (accessed 1 September 2015).

29 《上海市房地产登记条例》, commenced on $1^{\text {st }}$ July 2009. Chinese full text available on the website of Shanghai Municipal Government: www.shanghai.gov.cn/nw2/nw2314/nw3124/nw3177/nw3180/u6aw1966.html (accessed 1 September 2015).

${ }^{30}$ For a short summary of the issues and practice, see for example Liu Lin \& Zhou Ke, 《试论地方性法 规和部门规章之间的效力关系》，2009(12) Legal System and Society 365.

${ }^{31}$ Property Law of PRC, Article 246.
} 
both building and land registration. ${ }^{32}$ The most visible impact of such measures is that the registration authority can then issue a unified registration certificate to the proprietor, the socalled "two certificates in one". Instead of two separate certificates that proprietors in most parts of the country would apply for, namely the Certificate of Right to Land Usage (tu di shi yong quan zheng shu) and the Certificate of Building Ownership (fang wu suo you quan zheng shu), property owners in these areas would receive the Certificate of Right to Building and Land (fang di chan quan zheng shu).

Shanghai was one of the first to act under the initiative. In the same year as the commencement of Law of PRC on Urban Real Estate Administration, it legislated for the first version of Regulations of Shanghai Municipality on Registration of Real Estate (1995), which commenced the following year in March 1996. The Department for Housing and Land Administration was charged with the registration and issuing of the unified certificates of right to land and buildings. ${ }^{33}$ This arrangement continued to the present day even after the said Department was abolished in the restructuring of 2008, with its daily registration functions now taken over by the dedicated Division of Real Estate Registration. ${ }^{34}$ With much less rural land to be concerned with at the same time, property owners and parties involved in real property transactions in Shanghai would have been blissfully unaware of the complications and difficulties that most of country faced in the last twenty years with the surge of private ownership of housing and buildings. Two of the other three municipalities, namely Chongqing and Tianjin, adopted a similar structure of unified registration in 2004 and 2006 respectively. The only municipality standing out is Beijing, to be discussed in more details below.

Outside of the largely urbanised municipalities, a number of provinces endeavoured to adopt unified registration, with varying degrees of success. Unlike a municipality where a centralised agency can realistically deal with all registration matters on a daily basis, such as the Division of Real Estate Registration of Shanghai with its branches in each districts, the geographic span of a province practically deters any notion of a province-wide registration agency. Thus even where the provincial government authorised local unification of registration, it is often down to the prefecture-level government to put that into function. Guangdong Province was one of the earliest to legislate for unified registration in 1994, even before the commencement of Law of PRC on Urban Real Estate Administration. ${ }^{35}$ While prefectural cities such as Guangzhou and Shenzhen took on the initiatives early on, others, such as Foshan, waited much longer and some, such as Qingyuan, are still following the national model of divided registration more than twenty years after the commencement of provincial regulations. Elsewhere, Anhui Province passed its Regulations on Administration of Urban Real Estate Transactions in 2000,

\footnotetext{
${ }^{32}$ Law of PRC on Urban Real Estate Administration, Article 63.

${ }^{33}$ Regulations of Shanghai Municipality on Registration of Real Estate (1995), Article 5.

${ }^{34}$ Regulations of Shanghai Municipality on Registration of Real Estate (2009), Article 5.

${ }^{35}$ Regulations of Guangdong Province on Registration of Right to Urban Real Estate（《广东省城镇房 地产权登记条例》), first enacted in 1994, currently as amended in 1999, Article 3. Chinese full text available on the website of the Ministry of Land and Resources: www.mlr.gov.cn/zwgk/flfg/dfflfg/200411/t20041125 4423.htm (accessed 1 September 2015).
} 
announcing unified registration as one of its imperatives. ${ }^{36}$ Rather amazingly, however, between 2000 and 2015, not a single prefectural city actually put this into practice, rendering the provincial regulations a mere ambition. Many provinces are more realistic and instead handpicked one or two prefectural cities, often the most economically advanced, for unified registration, such as Dalian of Liaoning Province, Qingdao of Shandong Province, Xiamen of Fujian Province and Kaifeng of Henan Province. Still, the majority of China's 300-odd prefectural administrations follow the national regime of divided registration of land and buildings.

The situation in the capital Beijing Municipality warrants a mention, as it sheds further light on the great diversity in the legal and practical framework of real property registration. Despite explicit statutory provisions requiring all government above county-level to register right to use land and to duly issue certificates to right-holders, ${ }^{37}$ Beijing Municipality basically decided to not do this for the vast majority of private individuals who bought their houses or apartments in Beijing. Instead for most proprietors there has only been the need or facility for building registration since the early 1990s. In 2009, Beijing Municipal Bureau of Land and Resources issued a notification allowing registration of right to use land for an exclusive list of residential developments, which were only sold to foreigners and Chinese citizens from Hong Kong, Macau and Taiwan before 2002. ${ }^{38}$ However, for any development which is not on the list, the notification declared that "as the conditions are not met at the moment, any application to register the right to use land cannot be accept for the time being". ${ }^{39}$ The "notification" helpfully asked all district branches of the Bureau of Land and Resources to "actively, spontaneously and patiently explain to any applicant the reasons why such application cannot be accepted for the time being", even if the document itself listed no reason whatsoever. It also gave the reassurance that transactions or management of the building by the owner should not be affected by the absence of Certificate of Right to Land Usage. Furthermore, providing the Certificate of Building Ownership should suffice for any transfer, lease or mortgage of the property..$^{40}$ It certainly seems awkward that nearly thirty years after the commencement of Law of PRC on Land Administration, the capital of the People's Republic simply declared that the law had not been and would not be followed "for the time being". Conversely, if having one certificate is enough for tens of millions of proprietors of Beijing, why would it not be enough anywhere else in China? Is there any good reason to insist on registering an apartment with one government department and then the land which it is on with another department three days later?

\footnotetext{
36 《安徽省城市房地产交易管理条例》, enacted in 2000, Article 4. Chinese full text available on Anhui Government website: www.ah.gov.cn/userdata/dochtml/1/2013/7/12/7034757825156.html (accessed 1 September 2015).

${ }^{37}$ Law of PRC on Land Administration, Article 11.

38 “Notification by Beijing Municipal Bureau of Land and Resources about Problems regarding Registering Land for Former Foreign-sale Commodity Housing"（《北京市国土资源局关于原外销商 品房土地登记有关问题的通知》), $17^{\text {th }}$ September 2009. Chinese full text available on the website of Beijing Municipal Bureau of Land and Resources: www.bigtj.gov.cn/art/2009/11/4/art $2490362 . h t m l$ (accessed 1 September 2014). ${ }^{39} \mathrm{lbid}$, Article 3.

${ }^{40} \mathrm{Ibid}$, Article 4.
} 


\section{Towards Unified Registration}

Judging by published opinions ${ }^{41}$ and the Interim Regulations, it seems that most people, including the State Council, agreed that there is no point in such repetition and division. The Interim Regulations start with the objective of "integrating real property registration" 42 , and reaffirms that "the State implements a unified registration system for real property" 43 first pronounced by the Property Law of PRC back in 2007. Against the background of division and diversity in the current system, the "unification" devised by the Interim Regulations as well as the draft Implementation Rules comes in both the content of registration and the administrative structure of registration.

\section{(i) Content of Unified Registration}

The Interim Regulations enunciates nine categories of rights to be covered by the unified registration, namely 1) collective ownership of land, 2) ownership of houses and other buildings and structures, 3) ownership of forest and trees, 4) right of contracted management of arable land, forest, grassland and other land, 5) right to use land for construction, 6) right to use land for house sites, 7) right to use sea areas, 8) easement, and 9) mortgage. ${ }^{44}$ There is a tenth category to cover "other real property rights that require registration according to law".

Looking back at all the legislation relevant to registration, examined above, it is clear that Property Law of PRC forms the spine of unified registration. Seven of the nine categories are rights specifically contained in the statute. The only two exceptions are ownership of forest and trees, governed by Forestry Law of PRC, and the right to use sea areas, governed by Law of PRC on the Administration of Sea Areas.

Structured with the spine of Property Law of PRC, there is considerable reorganisation of most of the rights listed. Most noticeably these property rights are categorised according to their nature, rather than the specific subject matters as they are under existing law. For example, collective ownership of rural land is no longer divided according to the physical nature into grassland, forestland and other land, respectively governed by the Law on Grassland, Forestry Law and the Law on Land Administration under current regime. In accordance with the Property Law of PRC, collective ownership of land can encapsulate land, forestland, hills, grassland, wasteland and mudflats, ${ }^{45}$ with no particular need for further differentiation in registration. Unlike the Law of PRC on Urban Real Estate Administration, the Interim Regulations also implicitly extend registration of building ownership to all buildings regardless

\footnotetext{
${ }^{41}$ E.g. Wang Chongmin，《我国不动产登记制度若干问题探讨》，2003(2) China Legal Science 48, at p.50; Liu Yan, 《由房地产权登记谈不动产统一登记制度》，2006(1) China Land 18, at p.20.

${ }^{42}$ Interim Regulations, Article 1.

${ }^{43}$ Interim Regulations, Article 4.

${ }^{44}$ Interim Regulations, Article 5.

${ }^{45}$ Property Law of PRC, Article 58(1).
} 
of whether they are urban or rural, again preferring to regulate property rights by their nature over the physical characteristics of the subject matter.

The tenth, catch-all "other rights" category allows further expansion of the scope and content of unified registration. Although it seems that neither the Interim Regulations nor the draft Implementation Rules have their mind set on what should be included at this stage. There are a number of candidates. Within the array of law and regulations explained above, the notable absentee from the unified registration structure is the right to aquaculture in waters and mudflats. This right is "protected by law" according to Article 123 of the Property Law of PRC. However, the actual registration requirements come not from the primary statute, Fisheries Law of PRC, but the "Measures" from the Ministry of Agriculture. ${ }^{46}$ Article 123 also protects right to mineral prospecting and right of mining. Nevertheless, the law governing such mineral rights is primarily concerned with licensing and control of right-holders possessing necessary technical capacity, with a general ban on transfer of such rights to others. ${ }^{47}$ It is debateable whether such rights are mainly proprietary in nature, or more of a license under strict administrative control. The third type of rights "protected" by Article 123 is the right to extract water. Here the applicable law presents such right as a permission granted by the water authorities rather than a freestanding property right. ${ }^{48}$ Thus although these rights are clearly provided for and protected by Property Law of PRC, there is considerable complication in such a mixture of proprietary benefits and administrative licensing. The Interim Regulations take no stance over whether any of them could be integrated into the new real property registration, while the currently vacant catch-all category could potentially leave the door open.

\section{(ii) Administration Structure of Unified Registration}

While the classification and reorganisation of property rights are exciting to property lawyers, for most people the direct impact of the Interim Regulations will be felt in the restructuring of administrative framework over real property registration.

The Ministry of Land and Resources, currently as "the State Council department in charge of land and resources", is to "direct and supervise" all real property registration matters in the whole country. ${ }^{49}$ In preparation for unified registration, the Ministry duly established the Immovables Registration Bureau as its dedicated agency for this undertaking. With land being the basis of all real property rights, and given the fact the Ministry and its predecessor have been in charge of land administration since the mid-1980s, it is inherently logical and convenient for the Ministry to be put in control. Still this realignment of responsibilities takes away functions, including those entrusted by statutes, from at least three other departments of the State Council, namely the Ministry of Housing and Urban-Rural Development, the

\footnotetext{
46 “Measures for Licensing and Registration of Aquaculture in Waters and Mudflats" (《水域滩涂养殖 发证登记办法》), Order No.9 of the Ministry of Agriculture (24 $4^{\text {th }}$ May 2010).

${ }^{47}$ Law of PRC on Mineral Resources (《中华人民共和国矿产资源法》), first enacted in 1986, currently as amended in 1996, Article 6.

${ }^{48}$ Water Law of PRC（《中华人民共和国水法》), first enacted in 2002, Article 48.

${ }^{49}$ Interim Regulations, Article 6.
} 
Ministry of Agriculture and the State Forestry Administration..$^{50}$ During the transitional period at least, there may even be uncertainty in the applicable rules in some areas as many of the "Regulations" or "Measures" were issued by those ministries no longer in charge of real property registration matters since $1^{\text {st }}$ March 2015. Nevertheless, in the long run, having one central government department in charge of all real property registration is certainly a major improvement on the existing arrangements where responsibilities are scattered amongst half a dozen agencies.

Outside of the central government, the Interim Regulations require that all local government at county-level or above must designate a single government department as the real property registration authority of the area. The said department is in charge of real property registration matters, under the guidance and supervision of the real property registration authority at the level above. ${ }^{51}$ In practice this is likely to mean that department, bureau or division of land and resources at provincial or prefectural level will take over from other counterparts at the level, similar to what is expected of the Ministry of Land and Resources at central government level.

And the realignment of powers and responsibilities is not just among different departments of the same government, but also between the department and the government as a whole. The Interim Regulations make it amply clear that a specified government department designated as the real property registration authority by the government will be solely in charge of all real property registration matters. ${ }^{52}$ Without such uniformity, across those nine statutes enacted and amended over thirty years, there is a real sense of disorganisation, if not contradiction, in terms of whether registration should be handled by the local government as an entity or one particular department within the government. For example, Law of PRC on Urban Real Estate Administration specifies a single department for registration. Law of PRC on the Contracting of Rural Land and the Law of PRC on Grassland on the other hand allocate the responsibility on the whole government. Law of PRC on Land Administration and Law of PRC on Guarantee split things even further, by assigning some of the registration duties to the whole government, such as collective ownership and right to use land for construction, while handing over other registration duties, such as that of easements or mortgages, to a particular department of the same government. While this may appear to be a minor technicality, such complication does have very tangible impact, in relation to, inter alia, defendant in administrative lawsuits and source of compensation if applicable.

The defendant in an administrative lawsuit is the administrative body that took the specific administrative action in question, ${ }^{53}$ such as registration of an apartment in the name of another person. Under current law, therefore, if an erroneous registration occurs in relation to an apartment, the plaintiff must sue the local government for error in registration of the right to use land, but separately sue the department of building or construction of the same

\footnotetext{
${ }^{50}$ Excluding the State Oceanic Administration, which is a subordinate to the Ministry of Land and Resources in the first place.

${ }^{51}$ Interim Regulations, Article 6.

52 Interim Regulations, Article 6.

${ }^{53}$ Law of PRC on Administrative Litigation (《中华人民共和国行政诉讼法》), first enacted in 1989, currently as amended in 2014, Article 26.
} 
government for error in registration of the building. Moreover, Law of PRC on Administrative Litigation added a new provision on expected attendance by government official in administrative litigation in its latest amendment, with effect from $1^{\text {st }}$ May 2015. The "leading official" (fu ze ren) of the administrative body being sued "should" (ying dang) attend the court hearing of any administrative lawsuit against the body. If the person cannot appear in court, the official in charge of affairs corresponding to the litigation at the administrative body should be appointed to attend the court hearing. ${ }^{54}$ Thus under the existing structure of registration but with the new law on administrative lawsuit in place, if an individual sues over an erroneous registration of his or her right to use land for construction of, say, a single cottage, the expectation is that the mayor of the prefectural city "should" appear in court. Taking into account the fact that there are a dozen prefectural cities with population over ten million and more than fifty prefectural cities with more than five million people, it does seem rather excessive by any standard to expect the mayor, or even his or her appointed official at prefectural government level, to appear in court in every case of erroneous land registration. They would be undoubtedly thankful that once the changes required of by the Interim Regulations are in place, it would be the head of the real property registration section who has to deal with such litigation. The uniform clarification and appropriate allocation of duties and responsibilities over real property registration are certainly welcome progress promoted by the Interim Regulations.

Along the same vein of uniformity and clear responsibility, the Interim Regulations also anchors the actual registration work on the real property registration authority at county level. All real property registration is to be carried out by the registration authority of the county where the real property is situated. ${ }^{55}$ The exception to this general rule applies only in municipalities and cities that have established urban districts (she qu de shi) ${ }^{56}$. Such a municipality or city can take the decision that the real property registration authority at its leve $\left.\right|^{57}$ will directly deal with the actual real property registration work of all its component districts. ${ }^{58}$ Prima facie, the Interim Regulations seem to have allowed the continuation of having registration work done at three different levels in different parts of the country. Importantly, however, the new structure is distinguishable from the existing arrangement in that there can never be any overlap of registration duties. Any county or urban district (of either a prefectural city or municipality) can only have one real property registration authority in charge of actual registration work. For a county, the real property registration authority is always the county registration body. For an urban district, the authority could be the city registration body, if the city has opted to adopt the exception. If not, the registration authority will be the county-level district registration body. The two alternatives are mutually exclusive unlike the current structure where authorities at each level have a share of powers and responsibilities of actual registration work at the same time.

\footnotetext{
${ }^{54}$ Law of PRC on Administrative Litigation, Article 3.

55 Interim Regulations, Article 7.

${ }^{56}$ This includes most of the prefectural cities. It is worth noting that for most prefectural cities, despite the name of "city", their administrative area would include much larger rural areas organised in counties, than the built-up core area organised in urban districts.

${ }^{57}$ I.e. at municipal or prefectural level respectively.

58 Interim Regulations, Article 7.
} 
The complexity of the existing system of real property registration and the audacity of the changes promoted by the Interim Regulations warrant an interim summary, before the examination of any problem or difficulty below.

The existing system is a mishmash of applicable provisions on registration from an array of statutes and subsidiary legislation or administrative orders. Many government departments at different level are charged with duties to administer the registration of some real property rights, but not others which are dealt with by a different department of a different government under a different statute. In most parts of the country, a typical urban dweller will need to register his or her apartment separately from the right to use the land the apartment occupies. An ordinary farmer will need to register the right to build on land used for house sites, the building that is his or home, the right to cultivate land under contracted management, the right to trees over the land, the right to use grassland, and so on, all with different government or government departments under different statutes. Through local regulations and practices, some municipalities or prefectural cities, such as Shanghai and Guangzhou, have moved away spontaneously from such complexity into something of a unified registration of land and buildings. But these are by far the minority in a nationwide system characterised by complexity and inconvenience.

The vision of unified registration promoted by the Interim Regulations is as grand as the problem it endeavours to tackle. There will be a unified register of all real property rights. It will be operated by a single registration authority. A single, designated government department will direct and supervise the operation of such unified registration at each level, which is in turn under the guidance and supervision of the department at a superior level, all the way to the newly established Real Property Registration Bureau, under the Ministry of Land and Resources of the State Council. Some local variations are still permitted on specific issues but within the more clearly structured framework laid down by the Interim Regulations and the draft Implementation Rules once these are formalised. Overall there will be a unified system of real property registration in all of China, as first envisaged by the Property Law of PRC in 2007. It may be fair to say that the reform should be welcomed by anyone with some appreciation of the current status of real property registration in China.

\section{Progress and Difficulties}

The government projected that it would take three years to establish the unified registration system in the whole country. A platform for information sharing and queries would be operational in four years. ${ }^{59}$ During the transitional period, any registration certificate issued under pre-existing law or regulations remain valid. ${ }^{60}$ With some major changes to be

\footnotetext{
59 "China Exclusive: Unified property registration to curb corruption", Xinhua News Agency (10 $0^{\text {th }}$ May 2014), news.xinhuanet.com/english/indepth/2014-05/10/c 133324075.htm (accessed 1 September 2015).

${ }^{60}$ Interim Regulations, Article 33.
} 
implemented from central government down to counties and below in a large country, such timescale is perhaps always a challenging ambition.

Some prefectural cities made a very early start in implementing the unified registration. Xuzhou in Jiangsu Province and Luzhou in Sichuan Province both issued new Certificates of Real Property Right, the first ones in the country, on $1^{\text {st }}$ March 2015, the day when the Interim Regulations commenced. The Ministry of Land and Resources sent its Minister and one of his deputies respectively to Xuzhou and Luzhou to mark the occasion, making headline news. However, the real challenge is to spread the changes to over three hundred prefectural level regions and more than 2,800 county-level administration. Official news bulletin from the Ministry reported that at the end of March only 50 prefectural administrations and 101 county-level administrations had completed restructuring for unified registration, accounting for $16 \%$ and $4 \%$ of what needed to be done respectively. ${ }^{61}$ The figures quickly rose to 105 for prefectural level and 532 for county-level at the end of August. Still the Ministry was said to be unhappy with the progress made against the background of its original vision to complete all governmental restructuring at all levels before the end of 2015. ${ }^{62}$ Apparently there were considerable difficulties for governmental restructuring at county-level in terms of reassignment of responsibilities and redeployment of personnel.

In this regard it might be observed that this whole push for uniformity and integration, while certainly a much more positive and progressive approach than the existing disarray, is overly restrictive and prescriptive despite the great diversity of local administration across a vast country. For example, the universal insistence of registration being done at county-level registration authority in the Interim Regulations may inevitably encounter the reality that some of the smaller counties in China have only a fraction of the population of the larger ones. A few dozens of counties, mostly in inner land western provinces and regions such as Gansu or Xizang, have population below 20,000. Some of the larger counties in the east, such as Muyang in Jiangsu Province and Linquan in Anhui Province, have population over two million. Under the Interim Regulations, there is little room for manoeuvre in terms of the registration authority in charge of actual real property registration. It must be done at county-level. ${ }^{63}$ Thus some of the counties with 10,000 people must establish a comparable institution to that of a county accommodating two million in this uniform vision of unified real property registration. There is no provision for cross-county joint agency or any such alternative arrangement in the Interim Regulations, which might have served smaller counties more efficiently or cost effectively. To put such figures into perspective, the Land Registry, which serves 57 million people in England and Wales, only operates 14 offices across the country, or four million people on average per office. Scotland has only one register for its 5 million people. If China is to establish 2,800 county-level registration authorities for its 1.3 billion population, it would mean below half a million people on average per authority, equivalent to roughly only one ninth of the charge of a Land Registry office in England and Wales. In any case, it seems to be a rather stringent requirement that a county-level government of ten or fifteen thousand

\footnotetext{
${ }^{61}$ News Report (20 ${ }^{\text {th }}$ April 2015), Ministry of Land and Resources, www.mlr.gov.cn/xwdt/jrxw/201504/t20150420 1348258.htm (accessed 1 September 2015). 62 finance.people.com.cn/n/2015/0906/c1004-27546239.html (accessed 15 September 2015).

63 Interim Regulations, Article 7.
} 
people must establish a dedicated registration authority, operational within a year or so. It is arguably ineffective even if it is achieved. Nevertheless, the restructuring is in full motion and will very likely be completed in most regions with the Ministry of Land and Resources being the driving force.

Meanwhile, the media focus and public attention on such an ambitious and far-reaching reform have largely wandered away from administrative restructuring or the change of law and practices in real property registration. The immediate concern was whether it would affect the property market or the general economy. That fear seemed to have been allayed six months into the implementation of the Interim Regulations. Another common conjecture is that unified registration will lead to a new tax on real property holding. A popular suggestion was that unified registration of real property will assist in the ongoing anti-corruption campaign in targeting corrupt officials who acquired real property with unlawful income or through unlawful means.

Regardless of whether there were valid grounds for such views, from the perspective of a property lawyer, the reality is that the Interim Regulations and the pending Implementation Rules are to level the playing field to an acceptable minimum standard for all regions of China. For regions such as Shanghai Municipality, where unified registration of land and buildings under one government department has been in place for two decades, the changes could be minimal when the new structure is instated at some stage. But for regions where it had been traditionally difficult to make progress in this regard, this reform driven by the central government is an invaluable opportunity to rationalise and modernise the pre-existing structure of real property registration. For instance, four months after the commencement of Interim Regulations, the prefectural city of Chuzhou issued the first Certificate of Real Property Right in Anhui Province in July 2015. This was a step that no prefectural city took in the previous fifteen years despite provincial regulations to that effect, as mentioned above. With a third of the prefectural level administrations already on board within six months of the commencement of the Interim Regulations, there should be growing pressure for others to follow suit. Whether the whole project can be completed within the original timeframe of three years or not, and whether some county registration authorities would be able to operate efficiently or not, the Interim Regulations would undoubtedly be an important milestone in the development of property law and property registration in China. This is the first time that unified real property registration has become functional law and policies for most parts of China, rather than a vision of the future enshrouded in the abstractness of a statute.

\section{The Missing Components}

Bearing in mind the importance of such reform, there is nevertheless something notable by its absence from the reform, the implementation and the ensuing discussion. In the efforts to establish this embodiment of unified real property registration, there is little or no regard to the property law underlying or supporting any such registration.

Property Law of PRC makes it amply clear that the creation, modification, transfer or extinguishment of property right in real property only takes effect by registration. Subject to 
specific rules in other statutes, such creation, modification, transfer or extinguishment does not take effect without registration. ${ }^{64}$ To put it more bluntly, the effective operation of property law is dependent on valid and timely registration. But what the statute and the Interim Regulations failed to address is whether any registration entry is dependent on valid operation of property law. In other words, what should Chinese law make of a registration entry that should not have been entered according to existing rules and principles of property law? When is a registration entry "wrong"? How does property law deal with it and its consequences?

\section{(i) A-B-C Scenario}

A hypothetical scenario can best illustrate the difficult choice for a legal system here. The house concerned started in the ownership of $A$, who was the registered proprietor. Then $B$ managed to obtain registration of ownership in his name through means in breach of legal principles, including but not limited to, forgery, coercion, misrepresentation, lack of capacity and so on. $B$ then sold the house to $C$ who knew nothing of $A$ or what happened. $C$ is now registered as proprietor. Is C's registration valid? Who is recognised as the owner of the house?

Each jurisdiction has its own answer to such questions. Under the Australian Torrens system, not only would C be protected, even the registration of B is "immediately indefeasible", subject to the exception of fraud. ${ }^{65}$ In England and Wales, the registration in B's name is a "mistake", a technical term with considerable importance within the structure of Land Registration Act 2002. C's position is bolstered by "qualified indefeasibility", in the sense that as long as $\mathrm{C}$ has not caused or substantially contributed to the mistake, his registration is protected..$^{66}$ The act of registration always confers a legal title under the statute, regardless of whether there is any basis in general property law to support it. ${ }^{67}$ Under the new land registration law in Scotland, however, registration is only competent to the extent authorised by statutes and general property law principle. ${ }^{68}$ In such an example, C's registration would remain vulnerable until there has been at least one year of continuous possession since B's registration. ${ }^{69}$

Neither Property Law of PRC nor any other statutes have made it clear what approach China adopts in this regard. There have been some academic discussion or suggestion, but without law or regulations these are largely speculative. The only thing concrete that may shed some light here is the provision on bona fide acquisition of property in Property Law of PRC. ${ }^{70}$ Article 106 states that where any transfer of property to transferee is made by someone not entitled

\footnotetext{
${ }^{64}$ Property Law of PRC, Article 9.

${ }^{65}$ Ken Mackie, Ellise Bennett Histed \& John Page, Australian Land Law in Context (2012, Oxford University Press, South Melbourne), pp.225-229.

${ }^{66}$ Law Commission, Land Registration for the Twenty-First Century (2001, Law Com No 271), [10.13]

${ }^{67}$ Land Registration Act 2002, s.58.

${ }^{68}$ Land Registration etc. (Scotland) Act 2012, s.17; Scottish Law Commission, Report on Land Registration: Volume One (Scot Law Com No 222), [13.35].

69 Land Registration etc. (Scotland) Act 2012, s.86.

70 There are authors who argue that bona fide acquisition of real property should not be recognised in the current system of real property registration in China. See for example, Lu Chunya, 《论不动产登 记簿公信力和不动产善意取得制度的区别》，(2012) Contemporary Law Review 112, at 118.
} 
to deal with the property, the original owner of the property has the right to recover the property. However, if the transferee acquired the property satisfying all three conditions i) in good faith ii) at a reasonable price iii) having completed registration required by law, then the transferee will acquire ownership of the property. The original proprietor has no right to recover the property from such bona fide transferee, but only the right to sue the unauthorised transferor for losses suffered. ${ }^{71}$ Article 106 then succinctly extends this model for bona fide acquisition to property rights other than ownership.

With no special provision in any law or regulation to alter the general rule of Article 106, it must be applied to any case of real property registration, such as the example of A-B-C above. The end result bears a lot of similarities to the English approach of "qualified indefeasibility". In order for C's registration or ownership to be protected, C should have provided "valuable consideration" under English law, or paid a reasonable price under Article 106. C must not have caused or substantially contributed to the mistake under English law, or must been seen as bona fide under Article 106. Under both English and Chinese law, C's registration is protected without any delay unlike the new Scottish approach. But B's registration is not protected, unlike the model of "immediate indefeasibility" under Australian law. There are, however, significant components missing from the Chinese framework when examined alongside the English structure, most noticeably the interpretation of the concept of bona fide, and the availability of indemnity.

\section{(ii) Bona Fide}

For a couple of centuries, the concept of "bona fide" had huge influence over English property law thanks to the famous Doctrine of Notice, that a bona fide purchaser of a legal estate for value without notice would take the legal estate free of all prior equitable interests. Yet when English law came to construct a system of land registration, neither bona fide nor the Doctrine of notice was given any formal place in the legislation. Instead, some of the substances of bona fide and the Doctrine are preserved or transmuted into much more defined criteria. Most noticeably, a registered proprietor could be bound by interest of any person who was in actual occupation of the registered land at the time of the registration. However, if the interest was not known and the occupation was not obvious upon a reasonably careful inspection of the land, then the registered proprietor would not be bound by such interest. ${ }^{72}$ This effectively guides every purchaser of land into making a reasonably careful inspection of the land prior to a transfer in order to protect the position upon registration. Fundamentally, this avoids endless dispute with regard to whether any proprietor is bona fide or not.

Unlike English law, however, Chinese law does not have two hundred years of case law to construct any understanding of bona fide upon. Indeed as a relatively new jurisdiction largely following Civil Law traditions, at least in most private law areas, it has no formal system of case law precedents for such construction. Meanwhile, statutes or regulations have made no attempt to define "bona fide", despite provisions such as Article 106 affording such importance to the concept. So effectively this is an important legal concept harbouring significant practical impact that has no definition nor tests that is formally accepted by law.

\footnotetext{
${ }^{71}$ Property Law of PRC, Article 106.

${ }^{72}$ Land Registration Act 2002, Schedule 3 para 2.
} 
Academic opinions are also diverse in terms of what is bona fide in property transactions and whether it should be vary according to the type of property concerned. ${ }^{73}$ In the absence of workable rules, the common understanding has now come to the point that unless there is proof of actual knowledge of wrongdoings or defects in real property transactions, bona fide is presumed. ${ }^{74}$

The simplification of bona fide or equation with absence of actual knowledge is by no means a problem on its own. However, in the absence of proof of actual knowledge which may be difficult to come by in most cases, it does significantly lower the threshold set by Article 106 effectively to payment of price and completion of registration. With no expected practice such as "a reasonably careful inspection of the land", any potential purchaser or mortgagee should basically ask no question and deal with real property registration at face value. Not only does this put increased pressure on the new real property registration framework, it also exposes registered proprietors to potential loss of property through registration that they could hardly protect themselves from.

(iii) Case Law

The risk could be best illustrated by the case of Xu Guo Dong $v$ City of Nanjing Housing and Building Bureau. ${ }^{75}$ XGD was the registered proprietor of a flat in Nanjing. In 2004, XY, his daughter, obtained his Certificate of Building Ownership through deception and embarked on a plot of fraud. XY forged a Resident Identity Card bearing XGD's name and asked another person Zhu to impersonate XGD in a transfer of the flat purportedly from XGD to XY. After registration of the forged transfer, $X Y$ then approached China Everbright Bank with her newly acquired Certificate of Building Ownership, obtaining a loan of 225,000 RMB mortgaged against the flat. The mortgage was duly registered against the Certificate of Building Ownership in XY's name. The scam came to light a couple of years later following default on loan repayment and $X Y$ was prosecuted and sentenced to imprisonment for loan fraud in 2009. Following the criminal proceeding, City of Nanjing Housing and Building Bureau revoked the Certificate of Building Ownership in XY's name and annulled the forged but registered transfer from XGD to XY. However, the Bureau refused to remove the mortgage registered against the flat. In 2010, XGD sued the Bureau challenging such administrative decision but was unsuccessful both at first instance and on appeal.

The main reasoning provided in the decision is the straightforward application of Article 106. Everbright Bank did not know of XY's fraud. Everbright Bank paid reasonable price for the mortgage and it was duly registered. The court decided that XGD could ask for a new Certificate of Building Ownership in his name from the Bureau, but it should be burdened by the mortgage in favour of Everbright Bank.

\footnotetext{
${ }^{73}$ Cheng Xiao, 《论不动产登记簿公信力与动产善意取得的区分》, (2010) 22(4) Peking University Law Journal 524, at 537.

${ }^{74}$ Yin Tian, Property Law (2013, Peking University Press), p.220. (尹田，《物权法》)

${ }^{75}$ (2010) Ning Xing Zhong Zi No.132 (2010 宁行终字 132 号), reported in Guidance Cases for People's Court (Administrative Law Volume) (2014), China Legal Publishing House, p.228. (《人民法院指导案 例裁判要旨汇览 (行政卷)》)
} 
Perhaps because of the fact that it would have made no difference, the case report did not provide details of the use of the flat during the period concerned. However, the decision would still highlight the nonchalant approach the Chinese property law has towards dealing with real property on the mere basis of registration. Everbright Bank had no obligation to do anything with regard to the physical property, such as a reasonably careful inspection. The original registered proprietor would thus have no opportunity to alert a potential purchaser or mortgagee regarding his ownership. It is arguable that the current framework of real property registration in China is already overly reliant on documents and registration, to the extent of marginalising the physical aspects of real property usage, such as occupation and possession. The relationship between property law and property registration is undefined, which makes such a tendency even more problematic for innocent victims of fraud and other wrongs.

\section{(iv) Lack of No-fault Indemnity Mechanism}

The emphasis of registration records over physical control of land is not necessarily a misguided or unhelpful approach. In some regard this is a choice between "static security", protection of status quo as recorded on the register, and "dynamic security", protection of transactions involving registered property, that any property registration system will have to consider. ${ }^{76}$ The current practice in China, dominated by Article 106, seems to be largely in favour of dynamic security. In other words, it tends to protect the positive acquisition of property on the basis of registration, over the preservation of existing property rights that may be in conflict with later registration. However, such protection comes at a cost to the holders of existing property rights who may lose out on their property. ${ }^{77}$ Thus a registration system that opt for such an approach need to offer counterbalance to the cost and risk, often by the provision of state indemnity in case of such losses occurring. In a typical scenario of two innocent victims of the same fraud, such as the A-B-C example above, English and Australian systems have such indemnity mechanism which would compensate the losing innocent party monetarily, as the property is given to the other innocent party in a dispute. The new Scottish system has more exclusions of liability in place. ${ }^{78}$ But this is on the basis that registration does not positively change the position of property law, as explained above.

The current framework in China, by comparison, seems to be awkwardly placed in protecting dynamic security whilst offering no indemnity. A former registered proprietor who suffered loss, such as in this A-B-C scenario, can potentially claim against either or both of the wrongdoer $B$ and the registration authority. ${ }^{79}$ Property Law of PRC does not clarify whether the registration authority is strictly liable for the erroneous registration, or only on the basis of its own fault in effecting the registration. It could be argued that one provision of Property Law of PRC implies that the registration authority should be liable even if the fault lies with

\footnotetext{
${ }^{76}$ For more detailed explanation and analysis, see Pamela O'Connor, "Registration of Title in England and Australia: A Theoretical and Comparative Analysis" in Elizabeth Cooke (ed.), Modern Studies in Property Law, Volume 2 (Hart Publishing, 2003), ch 5.

77 For a fuller analysis of "costs" of registration approach, see Simon Cooper, "Resolving Title Conflicts in Registered Land", (2015) 131(Jan) Law Quarterly Review 108, at 118-127.

${ }^{78}$ Land Registration etc. (Scotland) Act 2012, s.85.

${ }^{79}$ Interim Regulations, Article 29.
} 
someone else, as it is empowered by law to claim against the wrongdoer after paying out compensation. ${ }^{80}$ However, this understanding, if correct, has never been applied in practice. Instead the lower courts has been following the guidance issued by the Supreme People's Court, which only allocates liability in proportion to fault or negligence by the registration authority. ${ }^{81}$ The Interim Regulations, while making a reference to unspecified "provisions in Property Law of PRC", effectively remain silent on the issue. ${ }^{82}$ But the draft Implementation Rules seem to have adopted, or even extended the approach of fault-based compensation in the guidance from the Supreme People's Court by explicit reference to "fault" in the narrative for compensation. ${ }^{83}$ Claims against the registration authority must be founded on negligence or errors by its officials, including not carefully examining forged documents and materials submitted for registration. ${ }^{84}$ The liability is again proportioned according to the extent of the fault and its effect in causing the loss suffered. Only if officials of the registration authority colluded with the wrongdoers in causing loss to former registered proprietor would the registration authority become jointly liable with the wrongdoer for all the loss. ${ }^{85}$

To use the case of XGD above as an illustration, the most that XGD could hope to claim against the registration authority would be a proportion of the loss he suffered as a result of discharging the RMB 225,000 mortgaged loan plus interest, likely on the basis of the fact that registration officials failed to uncover the forged Resident Identity Card used by the impersonator in the fraudulent transfer. This will very unlikely be seen as the main cause for the loss, as it was certainly not as significant as the fraudulent acts perpetrated by the convicted fraudster and her assistant. It is certainly not the only cause for the loss suffered. Therefore the registered proprietor would have to recover some or even the majority of the loss from a convicted fraudster currently imprisoned for the crime. It is perhaps fair to say that in terms of getting compensation, for many registered proprietor in such cases, it would be against the registration authority, or nothing. ${ }^{86}$

For a system which seems to favour dynamic security on the basis of registration, which in turn means added risk for registered proprietors even if they keep physical control of real property, it is arguably imperative to establish a no-fault state indemnity mechanism. The registration authority or the state has far more resources to absorb irrecoverable losses caused by the operation of real property registration. Yet in the ambitious push towards a unified registration framework of real property across China, law and regulations have been

\footnotetext{
${ }^{80}$ Property Law of PRC, Article 21.

${ }^{81}$ Rules of the Supreme People's Court on Several Problems in the Trial of Building Registration Cases (《最高人民法院关于审理房屋登记案件若干问题的规定》), Law Interpretation No.15 of the Supreme People's Court (5 $5^{\text {th }}$ November 2010), Article 12.

82 Interim Regulations, Article 29.

${ }^{83}$ Draft Implementation Rules, Article 129 para 1.

${ }^{84}$ Draft Implementation Rules, Article 129 para 3. This is an almost verbatim repeat of Article 12 of the interpretation from the Supreme People's Court.

${ }^{85}$ Draft Implementation Rules, Article 129 para 4. Again this is a near identical rule to Article 13 of the interpretation by the Supreme People's Court. The only addition is that the registration authority can claim afterwards against the official who colluded with the wrongdoer.

${ }^{86}$ This is of particular importance with the difficulty of claiming against the registration authority, a governmental body, as an ancillary in a civil law action instead of an administrative lawsuit. See Liu Baoyu，《不动产登记机构错误登记赔偿责任的性质与形态》，2012(2) China Legal Science 156, at 160.
} 
overlooking such an important component of a robust system of property registration. The policy makers seem to be more concerned with the registration authority recovering from its negligent employees ${ }^{87}$ than providing the general public with a no-fault indemnity that would boost the integrity of and confidence in the system of real property registration.

It is not the intention of this piece to suggest that China should follow the property registration model of any other country or jurisdiction. In fact, many jurisdictions have experienced or are pondering over significant changes to their approach. It took Australian states and territories the best part of a century to generally settle on "immediate indefeasibility" instead of "deferred indefeasibility". ${ }^{88}$ The Law Commission for England and Wales is working on a consultation paper over land registration, amidst influential academic opinions that the current positive registration system where registration will create rights should be abolished or significantly reconstructed. ${ }^{89}$ More recently Scotland abandoned its land registration structure introduced in 1979 and adopted a new approach in 2014 where registration does not give rise to any recognition of property rights. There is no perfect system that China can simply import and follow. Nevertheless, it is important for Chinese law to confront the difficulties faced by any other system of property registration, such as fraudulent registration and liability for the same. It is difficult enough to find a workable answer to such challenging questions. It is far more concerning that Chinese legislator and government have not even begun to ask these questions, despite moving in full motion to construct one of the largest property registration framework the world has ever seen.

\section{Conclusion}

Construed from a myriad of statutory and regulatory provisions scattered over three decades of legislative and administrative history, the existing system of real property registration in China is complex, ineffective and out-of-date. The Interim Regulations would unquestionable be a milestone in the efforts to create a modern unified system of real property registration. In line with the ambition and efficiency that China has been displaying in nationwide projects, within a short space of three to four years, the initiative would fundamentally transform the law and practice of real property at every level from the State Council to the registration authority in each of those 2,800 county-level administration.

In spite of the progress the reform has made and will make in due course, it may be observed that it is making little to no effort to address the relationship between real property registration and property law. The existing law in this regard is arguably insufficient and not suited to a streamlined and modernised real property registration system, especially in areas such as interpretation of bona fide transaction, or liability for erroneous registration. It is

\footnotetext{
${ }^{87}$ Draft Implementation Rules, Article 129 para 1 \& 4. Article 30 of the Interim Regulations also enumerate assorted consequences for registration officials who act negligently or abuse power, ranging from administrative penalty against civil servants, civil law liability and criminal prosecution.

${ }^{88}$ See Mackie et al, Australian Land Law in Context (fn 65), p.219.

${ }^{89}$ Amy Goymour, "Mistaken Registration of Land: Exploding the Myth of 'Title by Registration'”, (2013) 72(3) Cambridge Law Journal 617, at p.650; Simon Gardner, "The Land Registration Act 2002 the Show on the Road", (2014) 77(5) Modern Law Review 763.
} 
hoped that Chinese legislator and government would duly turn their attention to the development of property law underlying property registration at some stage in the course of this significant reform project. 